\title{
Penerapan pembelajaran kooperatif tipe STAD untuk meningkatkan motivasi dan hasil belajar PKn
}

\author{
Sri Purwanti ${ }^{\text {a, }}$, $^{*}$ Abdul Gafur ${ }^{\text {b, } 2}$ \\ a SMP Negeri 7 Yogyakarta, Indonesia \\ ${ }^{b}$ Program Studi Pendidikan Pancasila dan Kewarganegaraan, Program Pascasarjana, Universitas Negeri \\ Yogyakarta, Yogyakarta, Indonesia \\ ${ }^{1}$ sripurwanti1968@gmail.com *; abdul_gafur@uny.ac.id
}

*korespondensi penulis

\begin{tabular}{ll}
\hline Informasi artikel & ABSTRAK \\
\hline Kata kunci: & Penelitian ini bertujuan untuk meningkatkan motivasi dan hasil belajar dengan \\
Motivasi, & penerapan pembelajaran kooperatif tipe Student Teams-Achivement Divisions (STAD). \\
Hasil belajar, & Teknik pengumpulan data menggunakan tiga instrument, observasi, angket dan soal tes. \\
Model STAD & Analisis data dilakukan dengan analisis deskriptif kualitatif untuk motivasi belajar serta \\
& angket dan kuantitatif untuk hasil belajar. Hasil penelitian menunjukkan peningkatan \\
& motivasi dan hasil belajar. Dilihat dari kondisi awal siswa yang mencapai kriteria \\
& sangat aktif hanya 17,6\%, kemudian bertambah menjadi 20,6\% pada siklus 1, kemudian \\
& pada siklus kedua bertambah menjadi 58,8\% dan di akhir siklus menjadi 91,2\%. \\
& Sedangkan dalam hasil belajar, pada tes awal belum ada atau (0\%) siswa yang \\
& mencapai Kriteria Ketuntasan Minimal (KKM) yaitu telah meraih nilai 75 ke atas, \\
& setelah tindakan siklus pertama ada peningkatan 47,1\% siswa.
\end{tabular}

Keywords:

Motivation, Learning result, STAD model

\begin{abstract}
This research is aimed to improve the students' motivation and leaning result using cooperative learning type Student Teams Achievement Division (STAD). The data collection technique used three instruments: observation, questionnaires and test questions. The data was analyzed using qualitative descriptive analysis for the leaning motivation and the quantitative and questionnaire for learning result. The results showed that the student motivation and learning grade increased. It could be seen from the initial conditions of students who achieved the very active criteria only $17.6 \%$, then increased to $20.6 \%$ in cycle 1 . Then on the second cycle increased to $58.8 \%$ and $91.2 \%$ at the end of the cycle. While to the learning results; the initial tests showed that the students who achieved the Minimum Completeness Criteria 75 or above were 0 after the application it increased to $47.1 \%$ in the first cycle, then in the second cycle $58.8 \%$ and the third cycle $91.2 \%$.
\end{abstract}

Copyright (C) 2018 Sri Purwandi dan Abdul Gafur. All Right Reserved

\section{PENDAHULUAN}

\section{Pendidikan}

Pancasila

dan

Kewarganegaraan adalah mata pelajaran yang penting dalam pembentukan warga negara agar dapat memahami dan mampu melaksanakan hak-hak dan kewajibannya untuk menjadi warga negara yang cerdas, terampil dan berkarakter kebangsaan. Hal ini mengandung makna bahwa melalui Pendidikan Pancasila dan Kewarganegaraan peserta didik diharapkan mampu untuk memahami, menganalisis dan menjawab masalah-masalah yang dihadapi oleh masyarakat, bangsa dan negaranya secara konsisten dan berkesinambungan (Zamroni dalam Hamidi \& Lutfi, 2010, hal 79).

Pendidikan Kewarganegaraan (PKn) merupakan mata pelajaran yang salah satunya mengemban misi dalam proses pembentukan watak dan karakter peserta 
didik yang sesuai dengan kepribadian bangsa. Karakteristik mata pelajaran PKn yaitu mengembangkan kompetensi kognitif, afeksi, dan psikomotor peserta didik, dengan menitikberatkan pengembangan ranah afeksi. Untuk membangun kemampuan afeksi peserta didik pada pendidikan dasar dan menengah, dibutuhkan kompetensi kognitif yang cukup memadai dalam membangun wawasan dan pengetahuan siswa tentang materi PKn.

Wawasan dan pengetahuan bukan merupakan hasil perolehan pasif yang didapat dari proses transfer informasi dari guru, tetapi merupakan pengetahuan yang diperoleh dari proses konstruksi dan rekonstruksi oleh peserta didik sendiri, karena proses demikian memperkuat ketajaman berpikir atau kemampuan berfikir kritis dari peserta didik, dan sekaligus dapat meningkatkan tingkat kepekaan peserta didik.

Berdasarkan data hasil observasi pada mata pelajaran PKn peserta didik di SMPN 7 Yogyakarta, peserta didik masih memiliki tingkat kesulitan dalam memahami materi yang disampaikan guru. Akibatnya hasil belajar PKn peserta didik masih rendah di bawah Kriteria Ketuntasan Minimal (KKM) yang telah ditetapkan dalam Kurikulum Tingkat satuan Pendidikan (KTSP)yaitu sebesar 75, khususnya di kelas 8E. Hal ini bisa dilihat dari hasil Ulangan Harian 1 (UH.1), dimana dari enam kelas pararel di
SMPN 7 Yogyakarta, kelas 8E memiliki nilai rata-rata yang paling rendah.

Beberapa faktor penyebab rendahnya hasil belajar siswa yang peneliti temukan antara lain kurang antusiasnya siswa dalam mengikuti pelajaran tersebut. Rendahnya hasil belajar siswa bisa diartikan sebagai kurang efektifnya proses pembelajaran di kelas. Hal ini sangat peneliti sadari bahwa, metode yang digunakan dalam pembelajaran kadang kurang bervariasi dan tidak menarik, sehingga siswa cepat merasa bosan dan cenderung pasif dalam mengikuti pembelajaran, sehingga $\mathrm{PKn}$ dirasakan sebagai pelajaran yang sulit untuk diterima.

Berdasarkan hasil wawancara yang peneliti lakukan dengan salah satu siswa kelas 8 E, diperoleh informasi bahwa rendahnya hasil belajar siswa selama ini disebabkan karena kurang percaya diri untuk bertanya kepada guru ketika mengalami permasalahan, dan guru kurang variatif dalam menggunakan metode pembelajaran, sehingga siswa cepat merasa bosan. Selain itu, dalam menyelesaikan tugas dan latihan, siswa jarang diminta mengungkapkan alasan terhadap hasil jawaban dari pemikirannya sehingga siswa sulit mengkomunikasikan ide dan pemikirannya dengan baik.

Untuk mengatasi permasalahan tersebut, diperlukan model pembelajaran yang dapat memberikan makna serta menyenangkan bagi peserta didik. Salah satu model yang dapat mengarahkan peserta didik untuk 
memperoleh pengalaman belajar secara langsung adalah model pembelajaran kooperatif. Cooperative Learning memberikan kesempatan yang sama kepada siswa yang memiliki kemampuan tinggi dan kemampuan rendah untuk belajar bersamasama (Slavin,2005, hal. 255). Cooperative Learning merupakan suatu teknik pemberian tugas kepada kelompok dan mengerjakannya, merupakan suatu teknik pemberian tugas, siswa didorong untuk menemukan dan mengonstruksi materi yang sedang dipelajari bersama-sama tentang apa yang mereka temukan atau mereka bahas. Pengetahuan dibentuk bersama-sama berdasarkan pengalaman serta interaksinya dengan lingkungan di dalam kelompok belajar, sehingga terjadi saling memperkaya diantara anggota kelompok (Marsh, 2010, hal 141)

Salah satu model pembelajaran kooperatif adalah model pembelajaran kooperatif tipe STAD (tipe Student TeamsAchievement Divisions). (Arends \& Kilcher 2010, hal 317) menjelaskan, "STAD involves student working together in groups that compete with each other". STAD melibatkan siswa bekerja bersama dalam kelompok dan masing-masing kelompok bersaing dengan yang lain. Bagian yang paling esensial dari Cooperative learning tipe STAD adalah adanya kerja sama anggota kelompok dan kompetisi antar kelompok. Siswa bekerja dalam kelompok untuk belajar dari temannya serta mengajar temannya.
Student Teams Achievement Division (STAD) merupakan salah satu strategi pembelajaran kooperatif yang di dalamnya beberapa kelompok kecil siswa dengan level kemampuan akademik yang berbeda-beda saling bekerja sama untuk menyelesaikan tujuan pembelajaran. Tidak hanya secara akademik, siswa juga dikelompokkan secara beragam berdasarkan gender, ras, dan etnis (Rusman, 2012, hal. 201). Dengan heterogenitas anggota dalam satu kelompok, diharapkan dapat memotivasi siswa yang berkemampuan lebih dengan siswa yang berkemampuan kurang dalam menguasai materi, sehingga tumbuh kesadaran dalam diri siswa bahwa belajar dengan model kooperatif tipe STAD cukup menyenangkan.

STAD terdiri dari lima komponen utama yaitu: (1) presentasi kelas, (2) belajar dalam kelompok, (3) tes individu, (4) penghargaan kelompok (Slavin, 2005, hal. 73). Kelebihan dari STAD adalah, dengan adanya tes individu yang berupa kuis, dapat meningkatkan tanggung jawab individu, karena nilai akhir kelompok dipengaruhi nilai kuis yang dikerjakan secara individu sehingga membuat siswa lebih termotivasi dalam mengikuti proses pembelajaran

Menurut Raymond dan Judith (2004, hal 11) menyatakan motivasi belajar adalah suatu nilai dan suatu dorongan untuk belajar, anak tidak hanya sudi belajar tetapi juga menghargai dan menikmati aktivitas belajar seperti mereka menghargai dan menikmati hasil belajarnya. Motivasi berhubungan erat 
dengan minat. Peserta didik yang memiliki minat lebih tinggi pada suatu mata pelajaran cenderung lebih memiliki perhatian yang lebih terhadap mata pelajaran tersebut, akan menimbulkan motivasi yang lebih tinggi dalam belajar.

Thursan (2005, hal 27) menyatakan bahwa motivasi memiliki beberapa manfaat yang sangat penting dalam kegiatan belajar, antara lain: 1) akan memberikan dorongan semangat kepada siswa atau mahasiswa untuk rajin belajar dan mengatasi kesulitan belajar, 2) mengarahkan kegiatan belajar siswa atau mahasiswa kepada suatu tujuan tertentu yang berkaitan dengan masa depan dan cita-cita, 3) membantu siswa atau mahasiswa untuk mencari suatu metode belajar yang tepat dalam mencapai tujuan belajar yang diinginkan.

\section{METODE}

Penelitian ini merupakan penelitian tindakan kelas dengan menggunakan metode pembelajaran kooperatif tipe Student teams achievement Divisions (STAD). Penelitian tindakan adalah suatu bentuk penelitian reflektif diri yang secara kolektif dilakukan peneliti dalam situasi sosial untuk meningkatkan penalaran dan keadilan praktik pendidikan dan sosial mereka, serta pemahaman mereka (Kemmis \& Taggart, 1988, hal 5-6).

Penelitian ini dilaksanakan pada pertengahan tahun pelajaran 2015/2016 yaitu mulai pertengahan bulan oktober sampai Nopember 2015 dengan mengambil lokasi penelitian di kelas 8E SMP Negeri 7 Yogyakarta yang berada di Jl. Wiratama 38 Tegalrejo Yogyakarta 55244.

Populasi dalam penelitian ini adalah siswa kelas 8E SMP Negeri 7 Yogyakarta tahun pelajaran 2015/2016 yang berjumlah 34 orang yang terdiri dari 14 orang siswa laki-laki dan 20 orang siswa perempuan yang pada test awal nilai tertinggi 84 nilai terendah 52,3. Nilai rata-rata kelasnya masih relatif rendah yaitu 73,7 dan hanya 51,5\% dari 34 anak yang mencapai KKM 75, dan berdasarkan pengamatan kelas tersebut menunjukkan kecenderungan pasif dan tidak kondusif dalam pembelajaran.

Data yang didapat adalah data kuantitatif dan kualitatif, maka untuk data: Motivasi belajar siswa terhadap pembelajaran diolah secara kualitatif dengan menghitung skor dari deskripsi masing-masing kolaborator dari setiap siklus yang dilakukan, serta angket motivasi yang diberikan setelah proses pembelajaran berakhir pada setiap akhir siklus.

Sedangkan hasil belajar dianalisis diolah secara kuantitatif dengan menghitung dan membandingkan skor pencapaian hasil belajar per individu dan persentase skor yang dicapai per kelas dari setiap siklus yang dilakukan.

\section{HASIL DAN PEMBAHASAN}

\section{Hasil Penelitian}

\section{Motivasi Belajar}

Dilihat dari kondisi awal siswa yang mencapai kriteri sangat aktif hanya 6 orang siswa atau hanya $17,6 \%$, kemudian bertambah menjadi 7 orang siswaatau 20,6\% pada siklus 1, bertambah lagi menjadi 9 
orang siswa atau $26,5 \%$ pada siklus 2 pertemuan 1, kemudian pada siklus kedua pertemuan 2 bertambah menjadi 20 orang siswa atau 58,8\% dan diakhir siklus menjadi 31 orang siswa atau mencapai 91,2\%, Hal ini sangat relevan dengan semakin tumbuhnya tanggung jawab siswa dan semangat berkompetisi antar kelompok.

Peningkatan aktivitas belajar siswa juga diikuti juga dari isian angket siswa. Hal ini bisa dilihat dari data hasil angket dimana siswa sudah tidak ada yang termasuk dalam kategori rendah. Pada siklus pertama terdapat 22 siswa atau 64,7\% masuk dalam kategori sedang dan 12 siswa atau 35,3\% masuk kategori tinggi. Kemudian pada siklus kedua terjadi peningkatan yang cukup signifikan, yaitu terdapat 18 siswa atau 52,9\% termasuk kategori tinggi dan 16 siswa atau 47,1\% masuk kategori sedang, sedangkan pada siklus ketiga sama dengan siklus kedua yaitu terdapat 18 siswa atau 52,9\% termasuk kategori tinggi dan 16 siswa atau 47,1\% masuk kategori sedang, tetapi dengan peningkatan skor.

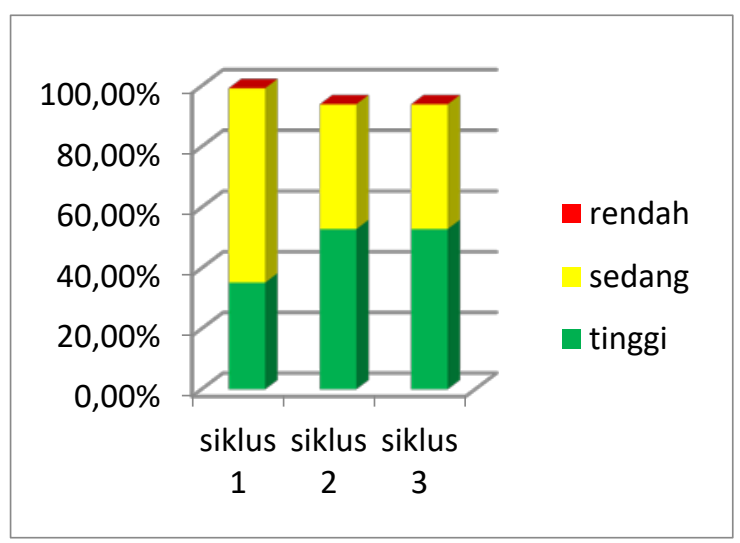

Diagram 1 Rekapitulasi Hasil Angket Siswa
Data rekapitulasi hasil angket siswa dan rekapitulasi aktivitas belajar siswa diatas yang semakin menunjukkan perubahan ke arah baik tersebut, dapat dimaknai sebagai meningkatnya motivasi siswa dalam proses pembelajaran. Siswa sudah mulai menguasai materi berbagai konstitusi yang pernah berlaku di Indonesia, merasa nyaman, saling membantu dalam memahami pelajaran, tidak merasa sendiri sehingga tumbuh rasa percaya diri, tumbuh sikap mau bekerja sama, tanggung jawab dan jiwa berkompetisi yang sehat.

\section{Hasil Belajar}

Motivasi serta semangat siswa untuk belajar PKn, diikuti dengan meningkatnya pemahaman siswa terhadap materi SK.2 memahami berbagai konstitusi yang pernah digunakan di Indonesia. Hal ini sangat signifikan dengan hasil belajar dari pembelajaran setelah dilakukan tindakan sebagaimana yang diharapkan peneliti.

Tabel 1. Rekapitulasi hasil belajar PKn

\begin{tabular}{|c|c|c|c|c|}
\hline Nilai & $\begin{array}{c}\text { Kondisi } \\
\text { awal }\end{array}$ & $\begin{array}{c}\text { Siklus } \\
\mathbf{1}\end{array}$ & $\begin{array}{c}\text { Siklus } \\
\mathbf{2}\end{array}$ & $\begin{array}{c}\text { Siklus } \\
\mathbf{3}\end{array}$ \\
\hline tinggi & 70 & 90 & 100 & 100 \\
\hline $\begin{array}{c}\text { ren- } \\
\text { dah }\end{array}$ & 20 & 50 & 60 & 70 \\
\hline Rerata & 38.5 & 72.6 & 78.8 & 83.5 \\
\hline tuntas & $0 \%$ & $47.1 \%$ & $58.8 \%$ & $91.2 \%$ \\
\hline $\begin{array}{c}\text { Daya } \\
\text { serap }\end{array}$ & $38.5 \%$ & $72.6 \%$ & $78.8 \%$ & $83.5 \%$ \\
\hline
\end{tabular}

Dalam hal jumlah siswa yang mencapai KKM yaitu siswa yang telah meraih nilai 75 ke atas pada kondisi awal atau hasil pretes belum ada atau $0 \%$, kemudian setelah tindakan atau siklus 1 ada kenaikan yang cukup signifikan, yaitu 
$47,1 \%$ dari 34 orang siswa telah mencapai KKM. Pada siklus ke 2 terjadi peningkatan menjadi 58,8\% dan di siklus ke 3 menjadi 91,2\% siswa yang telah mencapai KKM.

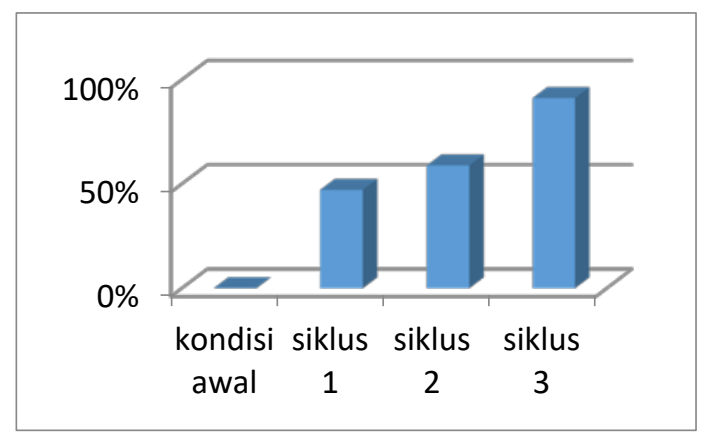

Diagram 2. Rekapitulasi Persentase Ketuntasan Belajar Siswa Per Siklus

Nilai tertinggi pada kondisi awal mencapai angka 70, setelah dilakukan tindakan terjadi peningkatan yang sangat signifikan yaitu mencapai 90 pada siklus 1, kemudian 100 di siklus ke 2 dan pada siklus ke 3 mencapai nilai 100 yang dapat dilihat pada:

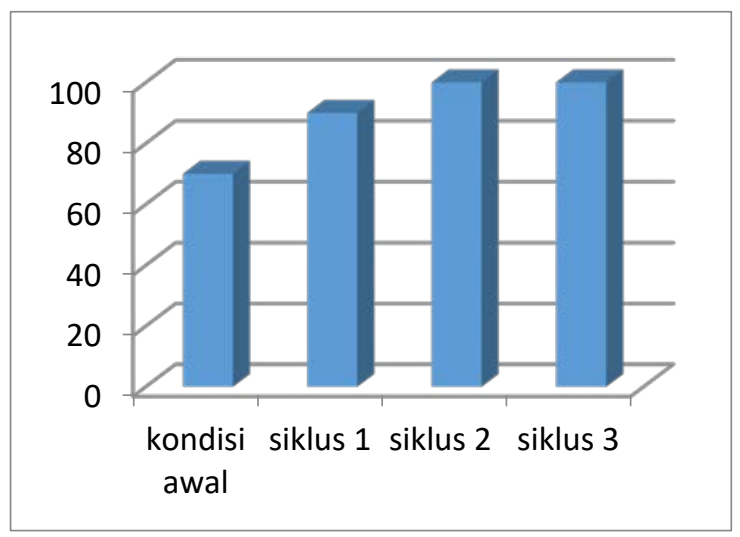

Diagram 3. Nilai Tertinggi Per Siklus

\section{Pembahasan}

Motivasi mempunyai peranan yang sangat penting dalam pencapaian prestasi belajar. Siswa yang telah termotivasi akan terdorong dan tumbuh semangat untuk melakukan sesuatu, fokus dalam mengikuti suatu pelajaran dan dampak positif yang ditimbulkan adalah tercapainya hasil atau prestasi pelajar yang tinggi.

Menurut Elliot Kratochwill, \& Cook (2000, hal. 363) ada dua faktor yang mempengaruhi motivasi, yaitu sikap dan kebutuhan. Jika siswa memiliki sikap positif terhadap pembelajaran, maka motivasi belajar akan meningkat, begitu juga sebaliknya. Demikian juga dengan kebutuhan siswa, jika pelajaran dianggap bermakna dalam kehidupan siswa, maka motivasi belajar siswa akan meningkat, begitu pula sebaliknya.

Berdasarkan hasil observasi Pada kondisi awal sebelum melaksanakan model pembelajaran kooperatif tipe STAD motivasi belajar siswa masih kurang, ini dapat dilihat dari aktivitas belajar PKn di kelas 8E masih rendah. Sebagian besar siswa masih pasif, belum berani mengajukan pertanyaan, belum percaya diri dalam menjawab pertanyaan yang dilontarkan guru, dan masih kurang kerja sama dalam menyelesaikan tugas. Tetapi pada pelaksanaan siklus 1 aktivitas siswa sudah mulai ada peningkatan, siswa sudah mulai berani untuk mengajukan pertanyaan bila ada materi yang disampaikan guru yang kurang mereka pahami, sudah mulai mau menjawab pertanyaan yang dilontarkan guru, siswa menyelesaikan tugas secara bekerja sama dengan temannya, berdiskusi dan mulai saling menjelaskan dan kadang mempertahankan pendapatnya. Peningkatan aktivitas siswa ini juga didukung dengan hasil angket yang diisi 
siswa setelah akhir siklus 1 yang menunjukkan bahwa 22 orang siswa menunjukkan sikap terhadap pembelajaran PKn dengan kategori sedang dan 12 orang siswa pada kategori tinggi.

Pada siklus 2 telah memenuhi harapan peneliti, siswa aktif belajar, aktivitas siswa terus ada peningkatan, siswa bertambah berani untuk mengajukan pertanyaan bila ada materi yang disampaikan guru yang kurang mereka pahami, bertambah percaya diri menjawab pertanyaan yang dilontarkan guru, siswa menyelesaikan tugas secara bekerja sama dengan temannya, berdiskusi dan mulai saling menjelaskan dan kadang mempertahankan pendapatnya. Hasil angket juga menunjukkan peningkatan sikap positif siswa pada pembelajaran PKn, yaitu terdapat peningkatan jumlah siswa yang masuk kategori tinggi.

Pada siklus 3, aktivitas belajar PKn pada siklus 3 telah memenuhi harapan peneliti, siswa semakin aktif belajar, aktivitas siswa terus ada peningkatan, siswa bertambah berani untuk mengajukan pertanyaan bila ada materi yang disampaikan guru yang kurang mereka pahami, bertambah percaya diri menjawab pertanyaan yang dilontarkan guru, siswa menyelesaikan tugas secara bekerja sama dengan temannya, berdiskusi dan mulai saling menjelaskan dan kadang mempertahankan pendapatnya, bahkan dalam pada waktu presentasi siswa antusias untuk maju ke depan ingin memaparkan hasil diskusi kelompoknya. Siswa yang tidak mendapat kesempatan untuk presentasi juga semakin aktif untuk memberikan tanggapan, masukan, saling mengoreksi, bahkan muncul pertanyaan-pertanyaan kritis yang dapat lebih mempertajam materi.

Berdasarkan pengamatan selama dilakukannya penelitian, ada beberapa temuan, yakni adanya perubahan sikap dalam pembelajaran. Siswa tumbuh sikap mau bekerja sama, saling membantu dalam memahami pelajaran, siswa lebih bertanggung jawab terhadap kelompoknya, serta tumbuh sikap berkompetisi yang tinggi. selain itu siswa tumbuh rasa percaya diri, tidak merasa sendiri, merasa nyaman untuk bertanya dan mengungkapkan ide dan gagasannya. Hal ini dapat peneliti lihat dari berkurangnya kesenjangan antar siswa dan terjadi pertemanan yang lebih sehat.

Penelitian ini mempunyai keterbatasanketerbatasan, sehingga diharapkan akan membuka kesempatan bagi peneliti lainnya untuk melakukan penelitian sejenis dengan lebih baik lagi, yang akan berguna bagi perluasan wawasan keilmuan. Keterbatasanketerbatasan tersebut diantaranya sebagai berikut:

Dalam melaksanakan penelitian ini, peneliti memiliki keterbatasan tenaga, waktu, alat, dan prasarana penelitian, sehingga peneliti tidak dapat melaksanakan penelitian secara sempurna

Materi dalam penelitian ini terbatas pada materi konstitusi yang pernah 
digunakan di Indonesia, sehingga memungkinkan generalisasi yang terbatas

\section{SIMPULAN}

Pembelajaran kooperatif tipe Student Teams Achivment Divisions (STAD) dapat meningkatkan motivasi belajar PKn siswa SMP Negeri 7 Yogyakarta, khususnya untuk Standar Kompetensi (SK) memahami konstitusi yang berlaku di Indonesia. Hal ini dapat dilihat dari hasil angket motivasi setelah siklus 1 yang menunjukkan sudah tidak ada lagi yang masuk dalam kategori rendah dan terdapat 22 siswa atau 64,7\% kategori sedang dan terdapat 12 orang siswa atau 35,3\% masuk kategori tinggi. Kemudian pada siklus 2 terjadi peningkatan yang cukup signifikan, yaitu 18 siswa atau 52,9\% termasuk kategori tinggi dan 16 siswa atau 47,1\% masuk kategori sedang, sedangkan pada siklus 3 sama dengan siklus 2 yaitu 18 siswa atau 52,9\% termasuk kategori tinggi dan 16 siswa atau 47,1\% masuk kategori sedang tetapi dengan peningkatan skor. Peningkatan hasil angket motivasi juga keaktifan siswa dalam mengikuti pembelajaran. Berdasarkan hasil observasi, pada kondisi awal siswa yang mencapai kriteria sangat aktif hanya 6 orang siswa atau hanya $17,6 \%$, kemudian bertambah menjadi 7 orang siswa atau 20,6\% pada siklus 1 , bertambah lagi menjadi 9 orang siswa atau 26,5\% pada siklus 2 pertemuan 1, kemudian pada siklus kedua pertemuan 2 bertambah menjadi 20 orang siswa atau 58,8\% dan di akhir siklus menjadi 31 orang siswa atau mencapai 91,2\%, Hal ini sangat relevan dengan semakin tumbuhnya tanggung jawab siswa dan semangat berkompetisi antar kelompok.

Pembelajaran kooperatif tipe Student Teams Achivment Divisions (STAD) dapat meningkatkan hasil belajar PKn siswa SMP Negeri 7 Yogyakarta. Nilai pre-test diperoleh rata-rata nilai sebesar 38,5 dengan persentase ketuntasan kelas $0 \%$, pada posttest siklus I diperoleh rata-rata nilai sebesar 72.6 dengan persentase ketuntasan kelas $47,1 \%$, terjadi peningkatan nilai sebesar 34,1 poin. Pada post-test siklus II diperoleh nilai rata-rata sebesar 78,8 dengan persentase ketuntasan belajar 58.8\%, sehingga dapat diperoleh peningkatan skor sebesar 6,2 poin, dan pada post-test siklus ke III diperolah nilai rata-rata 83,5 dengan persentase ketuntasan kelas sebesar 91,2\%.

\section{DAFTAR PUSTAKA}

Arikunto, Suharsimi. (2010). Penelitian tindakan, untuk guru, kepala sekolah \& pengawas, Yogyakarta: Aditya Media.

Arends, R.L., \& Kilcher, A. (2010).Teaching for student learning (Becoming an accomplished teacher). New York: Routledge Ratlor.

Azwar, Saifudin. (2010).Penyusunan skala psikologi. Yogyakarta: UNY Press.

Elliot, S.N., Kratochwill, T.R \& Cook, J.L. (2000).Educational Ssychology: Effective teaching, Effective learning (3th ed). New York: McGraw Hill.

Hakim, Thursan. (2005). Belajar secara efektif. Jakarta. Puspa Swara.

Kemmis, S. \& Mc Taggart, R.,. (1988). The action research planer. $3^{\text {rd }}$ ed. Victoria.Deakin University. 
Lutfi, M. \& Hamidi, J. (2010) Civic education: antara realitas politik dan implementasi hukumnya. Jakarta: PT Gramedia Pustaka Utama.

Marsh,C. (2010). Becoming a teacher. Australia: an imprint of pearson educational.https://books.google.co.id /books

Rusman. (2012). Model-model pembelajaran, mengembangkan profesionalitas guru. Jakarta: Rajawali Pers.

Slavin R.E (1995).Cooperative leorning: theory, research, and practice ( $\left.2^{\text {nd }} \mathrm{ed}\right)$. Boston. MA:Simon\&Schuster.

Sudikin, dkk.(2010). Manajemen penelitia tindakan kelas, Insan Cendekia. 